Génét. Sél. Evol., 1987, 19 (3), 337-350

\title{
Genetic parameters for first lactation dairy traits in Friesian, Montbéliarde and Normande breeds
}

\author{
D. BOICHARD and B. BONAÏTI \\ Station de Génétique quantitative et appliquée, \\ I.N.R.A., Centre de Recherches de Jouy, \\ F78350 Jouy-en-Josas.
}

\begin{abstract}
Summary
Genetic parameters for dairy traits in first lactation (milk yield, fat and protein yields, fat and protein contents) were estimated in the 3 main French breeds by HENDERSON's method III. In the Normande and Montbéliarde breeds, they were estimated from records including progeny of 291 and 219 young unproven bulls respectively, whereas in the Friesian breed they were obtained from data of 342 young North American Holstein bulls used on pure European Friesian dams. Yields were expressed for a 305-day lactation length or multiplicatively corrected for lactation length according to the French evaluation system. Additional records of daughters of proven sires were included to improve the estimation of herd effects. Results were similar in the Normande and Montbéliarde and were consistent with the average literature data, whereas in the Friesian breed, heritability of fat content was very high $(0.79)$. In the 3 breeds. genetic variability of protein content was about half that of fat content. The genetic antagonism with milk yield was stronger for protein content than for fat content. While the genetic correlation between fat yield and content was positive, the corresponding correlation for protein traits seemed to be close to zero, or even slightly negative. Correlations between yield of one component and content of the other also appeared to be negative. Accordingly, if the selection goal is defined as maximising the useful yield while maintaining fat and protein content, the selection criterion must include fat yield, protein yield and protein content.
\end{abstract}

Key words : Dairy cattle, genetic parameters, protein yield, protein content.

\section{Résumé}

Paramètres génétiques des caractères de production laitière

en première lactation dans les races bovines Frisonne, Montbéliarde et Normande

Les paramètres génétiques des caractères laitiers en $1^{\text {re }}$ lactation (quantités de lait, de matière grasse et protéique, taux butyreux et protéique) sont estimés dans les 3 principales races françaises par la méthode III de Henderson. En races Montbéliarde et Normande, ils sont estimés à partir de 219 et 291 descendances de jeunes taureaux respectivement et, en race Frisonne, à partir de 342 descendances de taureaux de testage Holstein purs, d'origine nord-américaine, utilisés sur des femelles Frisonnes européennes pures. Les quantités sont exprimées pour une durée de lactation de 305 jours, ou sont corrigées préalablement pour la durée suivant la méthode utilisée dans le système français d'évaluation. Les performances des filles des pères sélectionnés sont prises également en compte dans l'analyse, de façon à mieux estimer les effets "élevages ». En races Normande et Montbéliarde, les résultats sont cohérents entre eux et conformes à la moyenne bibliographique, alors qu'en race Frisonne, l'héritabilité du taux butyreux apparaît très élevée $(0,79)$. Dans les 3 races, 
le taux protéique est 1,8 à 2,5 fois moins variable que le taux butyreux. Il est génétiquement corrélé de façon plus défavorable avec la quantité de lait. Alors que la corrélation entre quantité et taux de matière grasse est positive, la corrélation homologue pour la matière protéique semble faiblement négative, de même que les corrélations croisées (un taux avec la quantité de l'autre matière). En conséquence, si l'objectif est défini par le maximum de progrès sur la matière utile avec maintien des taux, la sélection ne doit pas porter sur la seule matière utile, mais doit également prendre en considération le taux protéique.

Mots clés : Bovins laitiers, paramètres génétiques, quantité de matière protéique, taux protéique.

\section{Introduction}

Dairy selection has long been oriented towards increasing milk or fat yield. However, as more and more milk is processed into cheese, emphasis is on protein production and on a generally more concentrated milk.

Search for the maximum gain in fat and protein yield, without reducing milk concentration, constitutes the new selection goal. A slight increase in protein content is also desirable. In France, breeders have been working in this direction since 1970 : the major dairy selection criterion, is useful yield, which combines protein and fat yield in the ratio of 1.2 to 1 .

Genetic parameters for useful yield and content and for milk yield have been estimated by BonaİTI \& MocQuot (1982). Depending on the population, a zero or slightly positive correlation was observed between useful yield and content.

Even though selection on useful yield maintains milk total concentration, it is now necessary to verify if genetic trends for protein and fat contents separately are not negative. The present study constitutes a preliminary step towards the separate evaluation of fat and protein yields and the possible definition of a new synthetic selection criterion, combining useful yield and protein content.

\section{Material and methods}

Data were extracted from the National Milk Recording files. They comprised first lactation records of females born from a registered AI sire and belonging to one of the three main French breeds : Friesian, Normande and Montbéliarde.

The analysis was conducted on 2 years of recording in Normande (calving between 1 September 1980 and 31 August 1982) and 3 years in Montbéliarde (calving between 1 September 1980 and 31 August 1983), in order to reach a sufficient accuracy, since the number of young bulls sampled each year in these breeds is 150 and 80 respectively.

The Friesian is no longer a pure breed, but it is progressively absorbed by the North American Holstein strain. Since 1978, the part of pure Holstein young bulls increased, and now there is no longer European Friesian sires undergoing progeny test. According to this trend, emphasis is on Holstein. But today, the female population is heterogeneous. However, at the beginning of the 80 th's, most of the dams were pure European Friesian cows, while a lot of young bulls were Holstein. Therefore, the data 
for analysis were chosen corresponding to the calving from 1 September 1981 to $31 \mathrm{Au}$ gust 1983. During this time, 342 pure Holstein bulls were tested with a crossed progeny, out of European Friesian dams.

Each of the 3 data sets comprised 2 populations : daughters of young bulls undergoing progeny test (about 10 to $15 \mathrm{p}$. 100) with at least 25 daughters per male distributed in at least 20 herds, and daughters of the most widely used proven sires. Herds with records for less than 4 heifers were disregarded. Table 1 summarizes the characteristics of the 3 data sets.

\section{TABLE 1}

Characteristics of the data sets.

\begin{tabular}{|c|c|c|c|}
\hline Breeds & Friesian & Montbéliarde & Normande \\
\hline Number of records & 335581 & 99058 & 91020 \\
\hline Number of daughters of sampling bulls & 23987 & 16148 & 13441 \\
\hline Number of proven bulls $\ldots \ldots \ldots \ldots$ & 234 & 101 & 95 \\
\hline Minimum number of daughters per proven bull . & 300 & 150 & 150 \\
\hline Number of sampling bulls $\ldots \ldots \ldots \ldots \ldots$ & $342^{*}$ & 219 & 291 \\
\hline Minimum number of daughters per sampling bull . & 25 & 25 & 25 \\
\hline Number of herds $\ldots \ldots \ldots \ldots \ldots \ldots$ & 27448 & 7322 & 8826 \\
\hline Number of herds with daughters of sampling bull . & 20520 & 5492 & 5401 \\
\hline \multicolumn{4}{|l|}{ Selection criteria of records } \\
\hline Calving date (month, year) & $9-81-8-83$ & $9-80-8-83$ & $9-80-8-82$ \\
\hline Age at calving (month) . . & $22-42$ & $24-42$ & $24-42$ \\
\hline Fat yield $(\mathrm{kg})$ & $20-500$ & $20-500$ & $20-500$ \\
\hline Protein yield $(\mathrm{kg})$ & $20-500$ & $20-500$ & $20-500$ \\
\hline \multicolumn{4}{|l|}{ Means } \\
\hline Lactation length (days) & 305 & 300 & 293 \\
\hline 305-day milk yield (kg) & 4728 & 4400 & 3770 \\
\hline Fat content $(\mathrm{g} / \mathrm{kg})$ & 38.7 & 36.8 & 40.8 \\
\hline Protein content $(\mathrm{g} / \mathrm{kg})$ & 30.6 & 31.8 & 32.7 \\
\hline
\end{tabular}

* Pure Holstein only.

The following variables were analysed: milk yield, fat and protein contents, fat and protein yields, lactation length (L) and ratio of protein to fat content.

Useful content and yield were also analysed. They were defined by a combination of fat and protein contents or yields, with weighting 1 and 1.2 respectively.

Yield traits were expressed for 305-day, or priorly corrected for lactation length by the multiplicative factor of the French dairy sire evaluation scheme (Poutous et al., 1981) :

$$
\text { corrected yield }=\text { total yield } \times 385 /(\mathrm{L}+80) \text {. }
$$

Correlation between corrected yield and lactation length was zero above 250 days of milking, when lactation length is strongly related to days open, while under this threshold, correlation between corrected yield and lactation length remained highly positive. 
Variance and covariance components were estimated using HENDERSON's method III (1953). As suggested by Hill et al. (1983), MEYer (1984) and VAN VleCK (1985), records of daughters of selected bulls were included in the analysis to increase connections between herds, because a lot of herds had only one daughter of sampling sire (table 1). The selected bulls were considered as fixed effects, and only young bulls contributed to the estimation of variances and covariances.

The following model was used :

$$
Y_{i k l m}=H_{i}+A_{j}+M_{k}+G_{1}+T_{l m}+E_{i j k l m n}
$$

where $Y_{\mathrm{ijklmn}}$ was the dairy record,

$\mathrm{H}_{\mathrm{i}}$ the herd effect,

$\mathrm{A}_{\mathrm{j}}$ the age effect,

$\mathrm{M}_{\mathrm{k}}$ the year $\times$ month of calving effect,

$\mathrm{G}_{1}$ the fixed effect of the sires group,

$\mathrm{T}_{\mathrm{lm}}$ the within group fixed effect of the proven sire or random effect of the young bull assumed to be normally distributed with zero expectation and variance $\sigma_{\mathrm{s}}^{2}$

and $\mathrm{E}_{\mathrm{ijklm}}$ the residual effect, assumed to be normally distributed with zero expectation and variance $\sigma_{\mathrm{e}}^{2}$.

Equations for herd effects were absorbed. Groups were defined according to year of birth of the sires. Approximate sampling errors of estimates were determined as described by Grossman \& NORTON (1974).

\section{Results}

Results are presented first for yields multiplicatively corrected for lactation length and for contents calculated over the whole lactation. They are subsequently compared to results considering the 305-day lactations.

Estimated heritability coefficients for the 3 breeds are reported in table 2. For milk yield, estimated heritabilities were close to 0.30 for Normande and Montbéliarde, but higher in Holstein (0.37). Estimates were slightly lower for yield of constituents, between 0.27 and 0.31 , except 0.21 for protein yield in Montbéliarde. Heritability of fat yield was slightly higher than of protein yield. Heritabilities of fat and protein content were similar, around 0.55 , in the Normande and Montbéliarde breeds. In the Friesian breed they were much higher for fat content $(0.79)$, but similar for protein (0.53). The additive genetic variance for lactation length was low, especially for the Friesian breed $\left(\mathrm{h}^{2}=0.03\right)$.

Genetic correlations are shown in tables 3,4 and 5. Correlations between yields were high. The relationship between milk and protein yields $(0.87$ to 0.92$)$ was more pronounced than between milk and fat yields $(0.60$ for Holstein breed, close to 0.84 for the others). Correlations between fat and protein yields $(0.83$ and 0.89$)$ were higher than between corresponding contents $(0.55$ and 0.59$)$ for Montbéliarde and Normande. In Holstein, these correlations differed less, being 0.73 for yields and 0.67 for contents. The antagonistic correlation between milk yield and content was higher for protein $(-0.43$ and -0.54$)$ than for fat $(-0.30)$ in Normande and Montbéliarde, while it was close to -0.50 for both characters in Holstein. Relationships between contents and yields of constituents were lower, and in some cases not significantly different from 
TABLE 2

Estimation of phenotypic $\left(\sigma_{p}\right)$ and genetic $\left(\sigma_{g}\right)$ standard deviations and heritabilities $\left(h^{2}\right)$ of dairy traits in the 3 French breeds.

\begin{tabular}{|c|c|c|c|c|c|c|c|c|c|}
\hline \multirow{2}{*}{$\begin{array}{l}\text { Breeds } \\
\text { Traits }\end{array}$} & \multicolumn{3}{|c|}{ Friesian } & \multicolumn{3}{|c|}{ Montbéliarde } & \multicolumn{3}{|c|}{ Normande } \\
\hline & $\sigma_{p}$ & $\sigma_{\mathrm{g}}$ & $\begin{array}{c}\mathrm{h}^{2} \\
\mathrm{~s}\left(\mathrm{~h}^{2}\right)^{*}\end{array}$ & $\sigma_{p}$ & $\sigma_{g}$ & $\begin{array}{c}\mathrm{h}^{2} \\
\mathbf{s}\left(\mathrm{h}^{2}\right)\end{array}$ & $\sigma_{\mathrm{p}}$ & $\sigma_{g}$ & $\begin{array}{c}\mathrm{h}^{2} \\
\mathrm{~s}\left(\mathrm{~h}^{2}\right)\end{array}$ \\
\hline $\begin{array}{l}\text { Length corrected } \\
\text { milk yield** }\end{array}$ & 807 & 492 & $\begin{array}{l}0.37 \\
0.03\end{array}$ & 755 & 406 & $\begin{array}{l}0.29 \\
0.03\end{array}$ & 726 & 410 & $\begin{array}{l}0.32 \\
0.03\end{array}$ \\
\hline $\begin{array}{l}\text { Length corrected } \\
\text { fat yield** }\end{array}$ & 31.5 & 17.5 & $\begin{array}{l}0.31 \\
0.03\end{array}$ & 29.1 & 15.1 & $\begin{array}{l}0.27 \\
0.03\end{array}$ & 31.1 & 16.6 & $\begin{array}{l}0.29 \\
0.03\end{array}$ \\
\hline $\begin{array}{l}\text { Length corrected } \\
\text { protein yield }{ }^{* *}\end{array}$ & 23.6 & 12.8 & $\begin{array}{l}0.29 \\
0.03\end{array}$ & 23.7 & 10.9 & $\begin{array}{l}0.21 \\
0.02\end{array}$ & 23.5 & 12.2 & $\begin{array}{l}0.27 \\
0.03\end{array}$ \\
\hline $\begin{array}{l}\text { Length corrected } \\
\text { useful yield** }\end{array}$ & 29.1 & 15.3 & $\begin{array}{l}0.28 \\
0.02\end{array}$ & 28.1 & 13.5 & $\begin{array}{l}0.23 \\
0.03\end{array}$ & 29.1 & 15.2 & $\begin{array}{l}0.27 \\
0.03\end{array}$ \\
\hline Fat content & 3.55 & 3.16 & $\begin{array}{l}0.79 \\
0.05\end{array}$ & 3.13 & 2.24 & $\begin{array}{l}0.51 \\
0.05\end{array}$ & 3.47 & 2.51 & $\begin{array}{l}0.52 \\
0.04\end{array}$ \\
\hline Protein content & 1.77 & 1.29 & $\begin{array}{l}0.53 \\
0.04\end{array}$ & 1.96 & 1.45 & $\begin{array}{l}0.55 \\
0.05\end{array}$ & 1.91 & 1.39 & $\begin{array}{l}0.53 \\
0.04\end{array}$ \\
\hline Useful content & 2.54 & 2.18 & $\begin{array}{l}0.74 \\
0.05\end{array}$ & 2.37 & 1.76 & $\begin{array}{l}0.55 \\
0.05\end{array}$ & 2.52 & 1.88 & $\begin{array}{l}0.55 \\
0.04\end{array}$ \\
\hline 305-day milk yield & 977 & 524 & $\begin{array}{l}0.29 \\
0.02\end{array}$ & 1011 & 495 & $\begin{array}{l}0.24 \\
0.03\end{array}$ & 940 & 499 & $\begin{array}{l}0.28 \\
0.03\end{array}$ \\
\hline 305-day fat yield & 37.7 & 18.3 & $\begin{array}{l}0.24 \\
0.02\end{array}$ & 37.9 & 17.9 & $\begin{array}{l}0.22 \\
0.03\end{array}$ & 39.4 & 19.9 & $\begin{array}{l}0.26 \\
0.03\end{array}$ \\
\hline $\begin{array}{l}\text { 305-day protein } \\
\text { yield }\end{array}$ & 28.8 & 13.6 & $\begin{array}{l}0.22 \\
0.02\end{array}$ & 31.7 & 13.6 & $\begin{array}{l}0.18 \\
0.02\end{array}$ & 30.5 & 15.0 & $\begin{array}{l}0.24 \\
0.03\end{array}$ \\
\hline $\begin{array}{l}\text { 305-day useful } \\
\text { yield }\end{array}$ & 35.5 & 16.4 & $\begin{array}{l}0.21 \\
0.02\end{array}$ & 37.6 & 16.7 & $\begin{array}{l}0.20 \\
0.02\end{array}$ & 37.6 & 18.6 & $\begin{array}{l}0.25 \\
0.03\end{array}$ \\
\hline $\begin{array}{l}\text { 305-day fat } \\
\text { content }\end{array}$ & 3.52 & 3.15 & $\begin{array}{l}0.80 \\
0.05\end{array}$ & 3.12 & 2.23 & $\begin{array}{l}0.51 \\
0.05\end{array}$ & 3.45 & 2.50 & $\begin{array}{l}0.53 \\
0.04\end{array}$ \\
\hline $\begin{array}{l}\text { 305-day protein } \\
\text { content }\end{array}$ & 1.74 & 1.29 & $\begin{array}{l}0.55 \\
0.05\end{array}$ & 1.94 & 1.46 & $\begin{array}{l}0.57 \\
0.05\end{array}$ & 1.89 & 1.39 & $\begin{array}{l}0.54 \\
0.04\end{array}$ \\
\hline $\begin{array}{l}\text { 305-day useful } \\
\text { content }\end{array}$ & 2.49 & 2.18 & $\begin{array}{l}0.76 \\
0.05\end{array}$ & 2.36 & 1.77 & $\begin{array}{l}0.56 \\
0.05\end{array}$ & 2.50 & 1.87 & $\begin{array}{l}0.56 \\
0.04\end{array}$ \\
\hline $\begin{array}{l}\text { Protein to fat } \\
\text { contents ratio }\end{array}$ & 0.061 & 0.049 & $\begin{array}{l}0.65 \\
0.05\end{array}$ & 0.067 & 0.046 & $\begin{array}{l}0.46 \\
0.04\end{array}$ & 0.060 & 0.039 & $\begin{array}{l}0.43 \\
0.04\end{array}$ \\
\hline Lactation length & 67.7 & 12.1 & $\begin{array}{l}0.03 \\
0.01\end{array}$ & 69.7 & 21.0 & $\begin{array}{l}0.09 \\
0.01\end{array}$ & 69.2 & 20.9 & $\begin{array}{l}0.09 \\
0.02\end{array}$ \\
\hline
\end{tabular}

Contents were expressed as $\mathrm{g} / \mathrm{kg}$, yields as $\mathrm{kg}$ and lactation length in days.

${ }^{*} s\left(h^{2}\right)$ the sampling error of heritability, on the second line.

** Length corrected yield is defined by : (total yield $\times 385) /($ lactation length +80 ) 


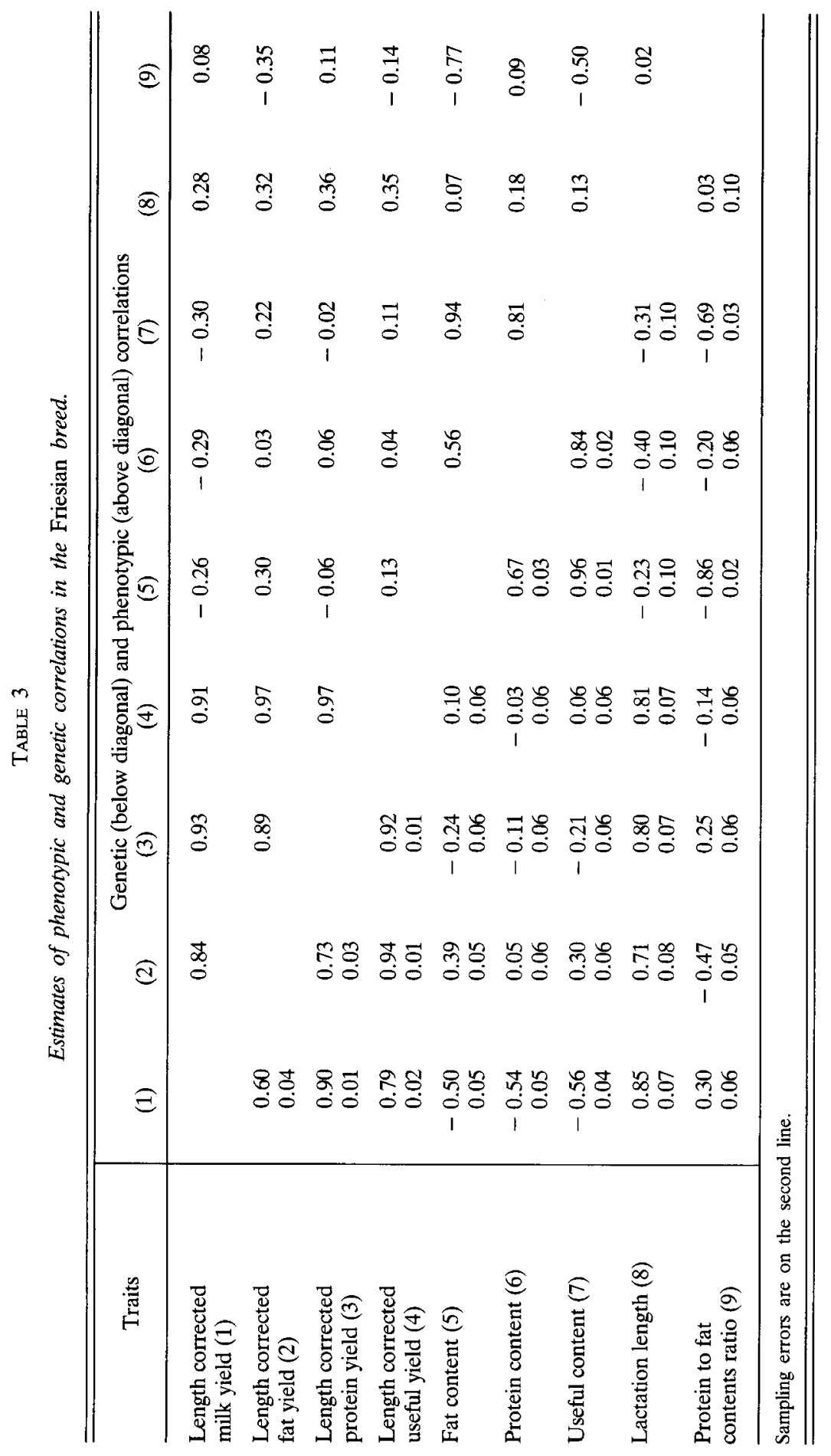




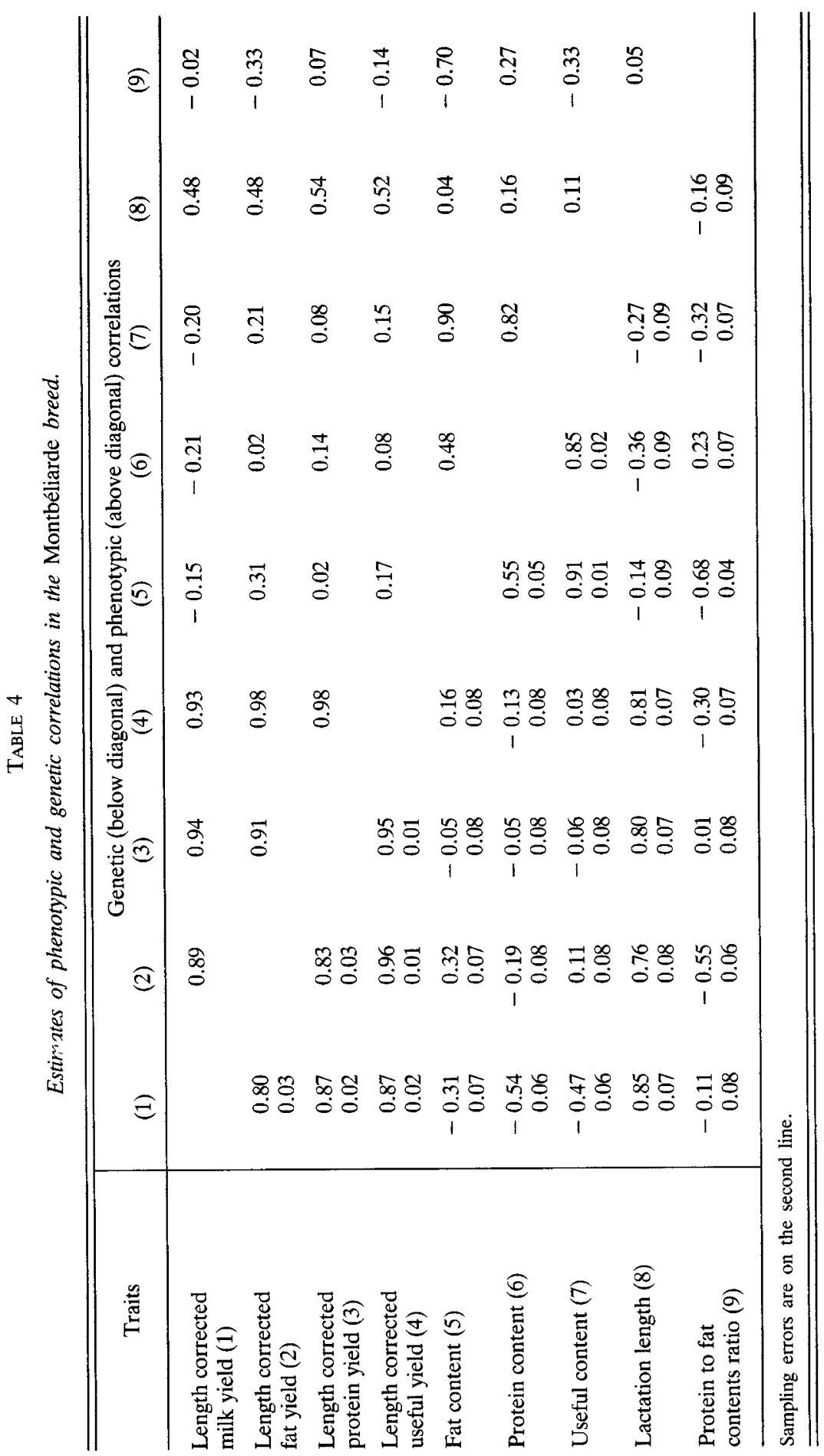




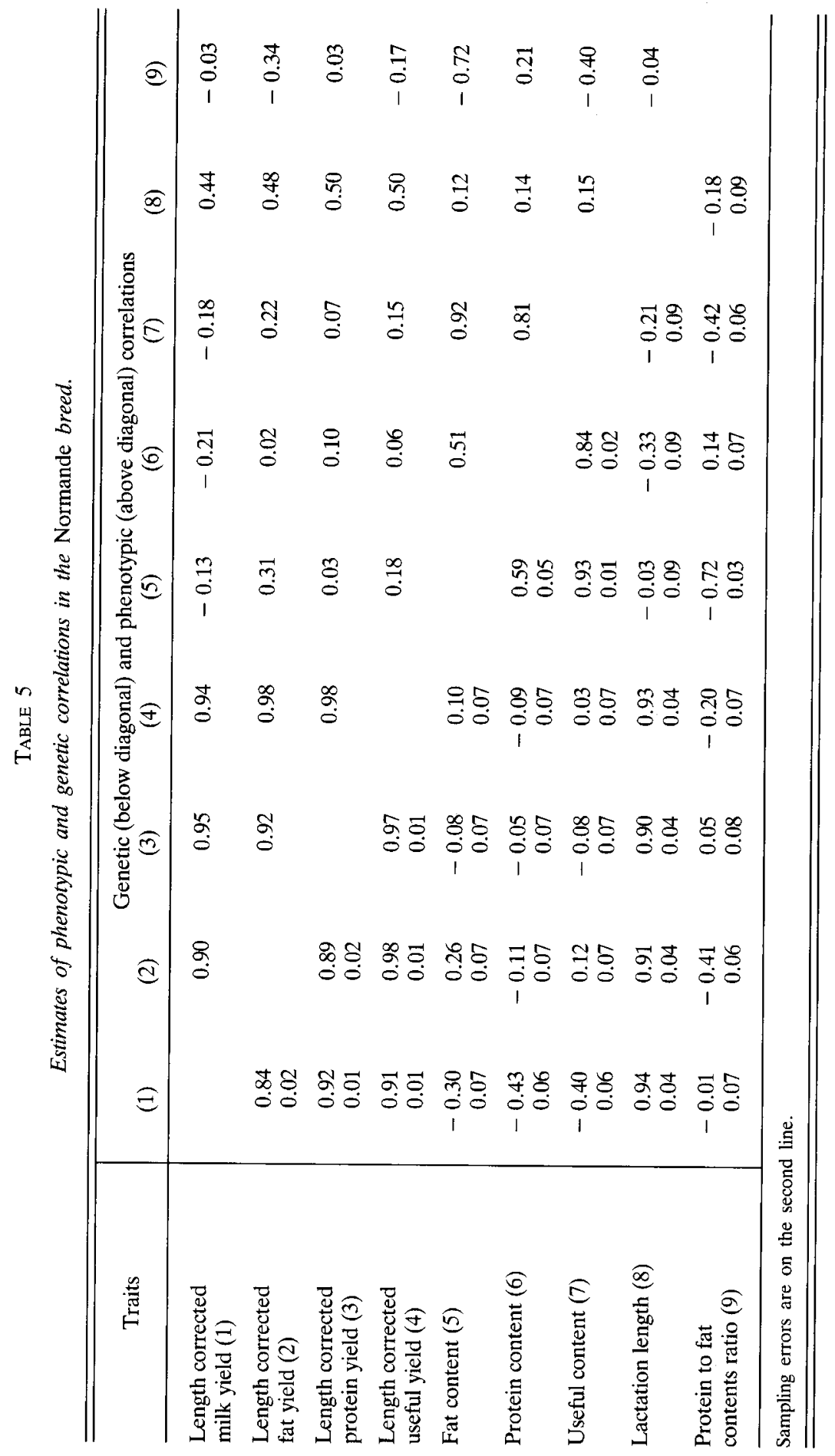


zero. The highest correlations were observed between fat content and fat yield $(0.26$ to 0.39 ). In contrast, correlations were always negative between protein content and protein yield $(-0.05$ to -0.13$)$. Correlations between yield of one component and content of the other were negative (from -0.05 to -0.24 ), except for a slightly positive estimate between fat yield and protein content in the Holstein breed (0.05).

Useful yield was positively related to fat content $(0.10$ to 0.16$)$, but negatively related to protein content $(-0.03$ to -0.13$)$.

When comparing these results with variables measured over a 305-day period, several differences may be pointed out. Heritabilities of 305-day yields were lower by 0.02 to 0.05 for Normande and Montbéliarde, and by 0.08 for Holstein. They were equal or slightly higher for contents (table 2). Similar genetic correlations were observed between milk yield and contents. The major difference concerned the genetic relationship between contents and yields (table 6). Correlations between 305-day traits were less favourable, by 0.07 to 0.12 for the correlation between fat yield and content, 0.06 to 0.09 between fat yield and protein content, 0.01 to 0.04 between protein yield and fat content, 0.05 to 0.11 between protein yield and content. The differences were smaller in Friesian than in Normande and Montbéliarde.

TABLE 6

Genetic correlations between yield and content.

\begin{tabular}{|c|c|c|c|c|c|c|c|c|}
\hline \multicolumn{3}{|c|}{ Traits } & \multicolumn{2}{|c|}{ Friesian } & \multicolumn{2}{|c|}{ Montbéliarde } & \multicolumn{2}{|c|}{ Normande } \\
\hline Yield & $x$ & Content & 1 & 2 & 1 & 2 & 1 & 2 \\
\hline Fat & & Fat & 0.39 & 0.32 & 0.32 & 0.20 & 0.26 & 0.15 \\
\hline Fat & & Protein & 0.05 & -0.02 & -0.19 & -0.25 & -0.11 & -0.20 \\
\hline Protein & & Fat & -0.24 & -0.25 & -0.05 & -0.09 & -0.08 & -0.11 \\
\hline Protein & & Protein & -0.11 & -0.16 & -0.05 & -0.15 & -0.05 & -0.16 \\
\hline
\end{tabular}

1 : length corrected yield.

$2: 305$-day yield.

The ratio of protein to fat content was characterized by a high heritability $(0.43$ to 0.65 ) and genetic variability (4 p. 100). But it was unfavourably related to fat content and fat yield, while its correlation with protein content or yield was low or zero. The estimated genetic correlations between lactation length and each of the contents were negative, although the phenotypic correlations were positive.

\section{Discussion}

In Normande and Montbéliarde, results for milk and fat agree with published data reviewed by MaIJALA \& HanNa (1974) and more recently by Barillet (1985). These results confirm the well established choice of selection on fat yield to increase it as 
much as possible while maintaining or improving fat content. However, the estimates obtained with the Friesian breed are very different : the genetic standard deviation (more than $3 \mathrm{~g} / \mathrm{kg}$ versus $2-2.5$ in the other cases) and heritability (0.79) of fat content are higher.

Three points lead one to assume that these surprising results do not depend on the model.

- The present data came from the progeny test program which guarantees a good distribution of daughters across herds and reduces possible effects of assortative mating or preferential treatment.

- From previous data (calving from 1977 to 1979), Bonaïrı \& MocQuot (1982) reported higher estimates of heritability and genetic standard deviation for useful content in the Holstein bull population $\left(\mathrm{h}^{2}=0.61, \sigma_{\mathrm{G}}=1.92 \mathrm{~g} / \mathrm{kg}\right)$ than for bulls of European origin $\left(\mathrm{h}^{2}=0.43, \sigma_{\mathrm{G}}=1.54 \mathrm{~g} / \mathrm{kg}\right)$.

- The sire effects obtained from the present analysis appeared to be highly correlated with the published proofs $(\mathrm{R}=0.95)$ and moreover, variabilities of both estimates were consistent. However, these sires'proofs were obtained from the National Sire evaluation which uses a very different methodology : records are corrected for genetic value of the dam; herd effects are estimated with all the lactations. Thus, dam and herd should not be a source of overestimation of the genetic parameters.

On the other hand, the sample of bulls seemed to be representative of the Holstein population. Out of these 342 bulls, 295 came from USA, and the genetic parameters estimated from this restricted sample were similar. Moreover, their sires and maternal grandsires (evaluated in USA) presented the same variability of proof as their contemporaries in the USA. Therefore, the genetic variability of fat content seems to be much higher in the Holstein strain used in crossbreeding with European Friesian than in pure breeding in North America. The interpretation of these results, which may involve major genes, heterosis or dominance, needs further investigation.

For lack of systematic recording of protein content in all countries, less data are available for this trait in comparison to fat content. Our results confirm the similar heritability of fat and protein content and genetic correlations with milk yield. They indicate a more marked antagonism between milk yield and protein content than the average value obtained by MAIJALA \& HANNA (1974). This result is consistent with more recent studies by Hargrove et al. (1981), PAPE et al. (1983), Schneeberger \& HAGger (1984) and Meyer (1985) who supplied more reliable estimates. In contrast, the independence or even antagonism between protein yield and content is atypical and does not agree with values obtained by MaIJALA \& HaNNA (1974) or with those of Hargrove et al. (1981), Alps et al. (1984) or Meyer (1985) who established a positive correlation between protein yield and content. However, results similar to ours were obtained in the dairy ewe, -0.09 to -0.19 (BARILlet, 1985 ; BARILlET \& BoICHARD, in press). Due to the mathematical relationship between traits (the multiplication by milk yield) correlations observed between protein and fat yield (around 0.85) were higher than between fat and protein content (around 0.60) in Montbéliarde and Normande. This point is consistent with published results. On the basis of these values it is easier of obtain a preferential variation in one of the two contents than in one of the yields. On the other hand, these correlations are not very different in Friesian. This can be due to the large variability of fat content. The ratio of the genetic standard deviation of fat content to that of protein content is 1.85 , and even 2.5 in the Friesian 
breed, and ranges between 1.36 and 1.38 for yields. Accordingly, protein matter is less likely to vary than fat.

Correlations between yield of one component and content of the other are in agreement with negative values recently obtained by HARGROVE et al. (1981) and especially PAPE et al. (1983), AlPS et al. (1984) and MEYER (1985). In contrast, the results of Maijala \& Hanna (1974) were mostly positive.

The possible decrease in protein content which would have negative technological consequences, cannot be totally neglected, even with selection exclusively based on solid yields. Today, the main selection criterion used in France is the useful yield. This trait takes an intermediate position between fat and protein yields with which it is highly correlated $(0.92$ to 0.98$)$. The corresponding useful content is closer to fat than to protein content. In the three breeds, the correlation between useful yield and content was always slightly positive $(0.03$ to 0.16$)$, contrary to previous estimates by BonAİTI \& Mocouot (1982). However, this correlation results from a positive relationship between useful yield and fat content $(0.10$ to 0.12$)$, and a negative correlation with protein content $(-0.03$ to -0.13$)$. Therefore this selection criterion may lead to a slight decline of protein content which must be compensated by a greater emphasis laid on selection for protein content. Selection on the ratio of protein to fat content is excluded, since it decreases fat content instead of increasing protein content which is less variable.

This expected decline of protein content suggests definition of a new selection goal, which maximizes fat and protein yield, while maintaining protein content.

TABLE 7

Asymptotic expected changes according to the selection criterion (Normande breed estimated genetic parameters).

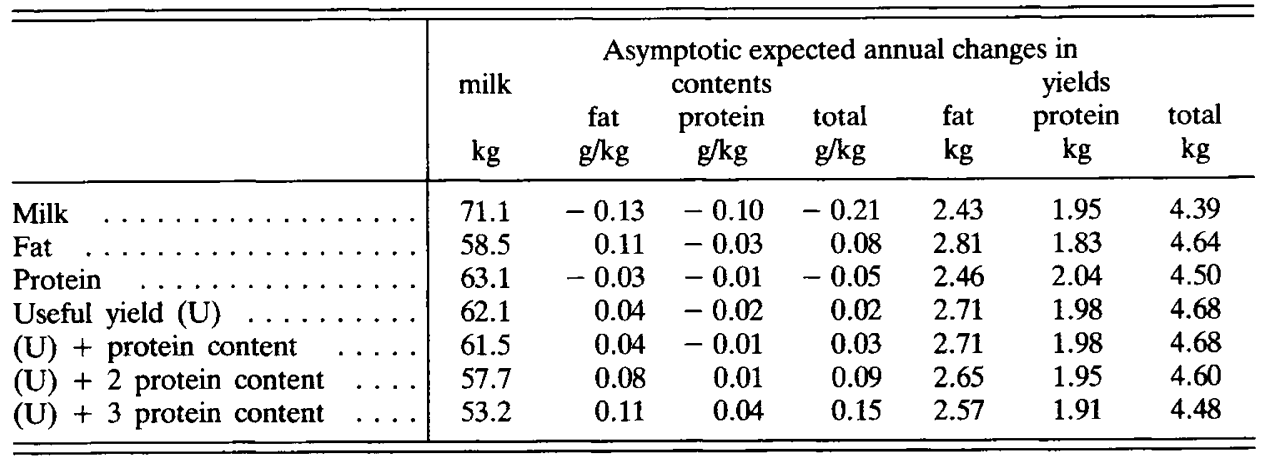

A new criterion may be chosen according to the theoretical changes in the different traits. The genetic parameters used for this prediction study were those estimated in the Normande breed, which are the closest to the average literature data. Asymptotic expected changes were estimated as described by RENDEL \& ROBERTSON (1950). 
The selection scheme considered, closed and intensive, was derived from DuCROCQ (1984). Assumptions on selection pressures on the 4 gene transmission pathways, sire-son, sire-daughter, dam-son and dam-daughter, were 5, 20, 3 and 100 p. 100 . Generation intervals were assumed to be $7.5,7.5,6.5$ and 5.5 years, respectively. Males were evaluated with 50 effective records of heifers, and bull's dams with at least 3 lactations. 10 p. 100 of the first-calvers were assumed out of unproven sires, and 90 p. 100 out of selected sires. The results under these hypotheses are shown in table 7 . The present selection criterion, the useful yield, seems to be relatively satisfactory, since the expected annual gain in fat and protein yield is maximum. However, protein content has to be taken into account in the selection criterion, to remain stable. But with a low weighting, protein content can be easily maintained and the loss of genetic progress in useful yield remains small (2 p. 100).

\section{Conclusion}

Estimates of genetic parameters obtained for the Normande breed are very close to the average literature data, except for an atypical slight antagonism between protein content and yield. The same relationship is observed in the Montbéliarde breed, which is due to a marked antagonism between milk yield and protein content. The Holstein breed crossed with European Friesian is characterized by very high heritability and genetic standard deviation for fat content. This point needs further investigations.

As shown by the yield-content correlations, selection on useful yield seems relatively satisfactory. It maintains useful content stable, but does not guarantee protein content, whereas fat content should be improved. It seems advisable to take protein content into account in the selection goal in the 3 breeds : in the Montbeliarde and Normande because of the slightly negative correlation between useful yield and protein content, and in the Friesian, which exhibits a decreased protein content due to Holstein infusion.

Received October, 24, 1986.

Accepted January 28, 1987.

\section{References}

Alps H., Reklewski Z., Averdunk G., 1984. Genetische Parameter für die Merkmale der Milchleistung unter besonderer Berücksichtigung des Eiweisses beim Fleckvieh in Bayern. 1. Einzelmerkmale. Züchtungskunde, 56, 88-98.

Barillet F., 1985. Amélioration génétique de la composition du lait de brebis : l'exemple de la race Lacaune. Thèse de docteur ingénieur, INA Paris Grignon.

Barillet F., Boichard D., 1987. Studies on dairy production of milking ewes. I. Estimates of genetic parameters for total milk composition and yield. Génét. Sél. Evol. (in press).

Bonaĩn B., Mocquot J.C., 1982. Etude de la production laitière des bovins. IV. Paramètres génétiques en première lactation. Ann. Génét. Sél. Anim., 14, 161-176.

Ducroco V., 1984. Conséquence sur le progrès génétique laitier d'une sélection sur des caractères secondaires chez les bovins. Génét. Sél. Evol., 16, 467-490.

Grossman M., Norton H.W., 1974. Simplification of the sampling variance of the correlation coefficients. Theor. Appl. Genet., 44, 332.

Hargrove G.L., Mbah D.A., Rosenberger J.L., 1981. Genetic and environmental influences on milk and milk component production. J. Dairy Sci., 64, 1593-1597. 
HEnderson C.R., 1953. Estimation of variance and covariance components. Biometrics, 9, 226-252.

Hill W.G., Edwards M.R., Ahmed M.K.A., Thompson R., 1983. Heritability of milk yield and composition at different levels and variability of production. Anim. Prod., 36, 59-68.

MaiJala K., HanNa M., 1974. Reliable phenotypic and genetic parameters in dairy cattle. $1^{\text {st }}$ World Congress on Genetic Applied to Livestock Production. Madrid, 7-11 october 1974, 1, 541-563. Ed. Garsi, Madrid.

MeYer K., 1984. Estimates of genetic parameters for milk and fat yields for the first three lactations in British Friesian cows. Anim. Prod., 38, 313-322.

MEYER K., 1985. Genetic parameters for dairy production of Australian Black and White cows. Livest. Prod. Sci., 12, 205-219.

Pape H.C. Von, Claus J., Kalm E., 1983. Schätzung genetischer Parameter in aufeinanderfolgenden Laktationen beim Angler Rind in Schleswig-Holstein. 2. Schätzung von korrelativen Beziehungen. Züchtungskunde, 55, 24-33.

Poutous M., Briend M., Calomiti S., Doan D., Felgines C., Steier G., 1981. Méthode de calcul des index laitiers. Bull. Tech. Inf., 361, 433-446.

RENDEL J.M., RoBERTSON A., 1950. Estimation of genetic gain in milk yield by selection in a closed herd of dairy cattle. J. Genet., 50, 1-7.

Schneeberger M., Hagger C., 1984. Genetic parameters for days open, milk yield, and fat and protein content of Swiss Braunvieh cows. Livest. Prod. Sci., 11, 261-268.

VAN VLECK L.D., 1985. Including records of daughters of selected bulls in estimation of sire component of variance. J. Dairy Sci., 68, 2396-2402. 